\title{
Chemical Analysis of Sediment Cores from the East Waterway (Everett, Washington)
}

\author{
E. A. Crecelius \\ N. S. Bloom \\ J. M. Gurtisen \\ Marine Research Laboratory \\ Sequim, Washington
}

June 1984

\author{
Prepared for \\ U.S. Army Corps of Engineers \\ under a Related Services Agreement \\ with the U.S. Department of Energy \\ Contract DE-AC06-76RLO 1830 \\ Pacific Northwest Laboratory \\ Operated for the U.S. Department of Energy \\ by Battelle Memorial Institute
}




\title{
DISCLAIMER
}

This report was prepared as an account of work sponsored by an agency of the United States Government. Neither the United States Government nor any agency thereof, nor any of their employees, makes any warranty, express or implied, or assumes any legal liability or responsibility for the accuracy, completeness, or usefulness of any information, apparatus, product, or process disclosed, or represents that its use would not infringe privately owned rights. Reference herein to any specific commercial product, process, or service by trade name, trademark, manufacturer, or otherwise, does not necessarily constitute or imply its endorsement, recommendation, or favoring by the United States Government or any agency thereof. The views and opinions of authors expressed herein do not necessarily state or reflect those of the United States Government or any agency thereof.

\author{
PACIFIC NORTHWEST LABORATORY \\ operated by \\ BATTELLE \\ for the \\ UNITED STATES DEPARTMENT OF ENERGY \\ under Contract DE-AC06-76RLO 1830
}

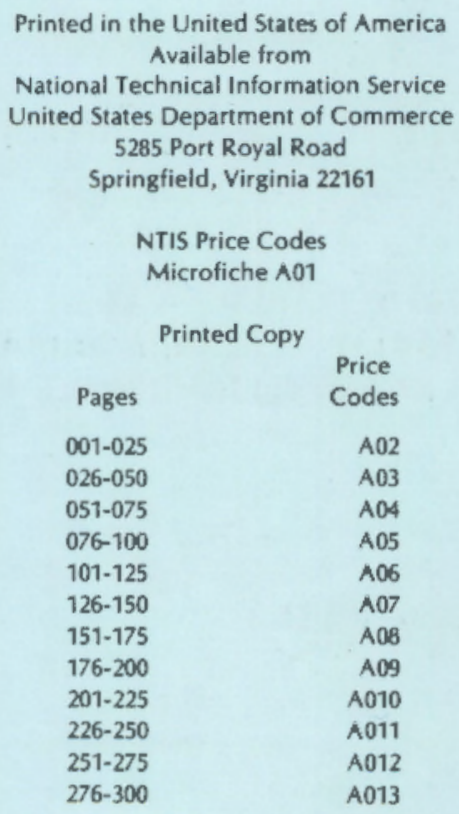


Fina] Report

CHEMICAL ANALYSIS OF SEDIMENT CORES FROM THE EAST HATERWAY

(EVERETT, WASHINGTON)

E. A. Crecelius

N. S. Bloom

J. M. Gurtisen

Marine Research Laboratory

Sequim, Washington

June 1984

Prepared for

U.S. Army Corps of Engineers, Seattle District under a Related Services Agreement with the U.S. Department of Energy

Contract 0E-AC06-76RLO 1830

Pacific Northwest Laboratory

Richland, Washington 99352 

Chemical data for two sediment cores from the East waterway of Everett, Washington, indicate that 20 to $30 \mathrm{~cm}$ of contaminated sediments are accumulating per year. The concentrations of several heavy metals ( $\mathrm{Pb}$, $\mathrm{Hg}$ and $\mathrm{Cu}$ ), polychlorinated biphenyls (PCBs) and petroleum hydrocarbons increase with depth in the sediments suggesting contamination of this waterway has varied by as much as a factor of 10 during the last 5 years. 


\section{CONTENTS}

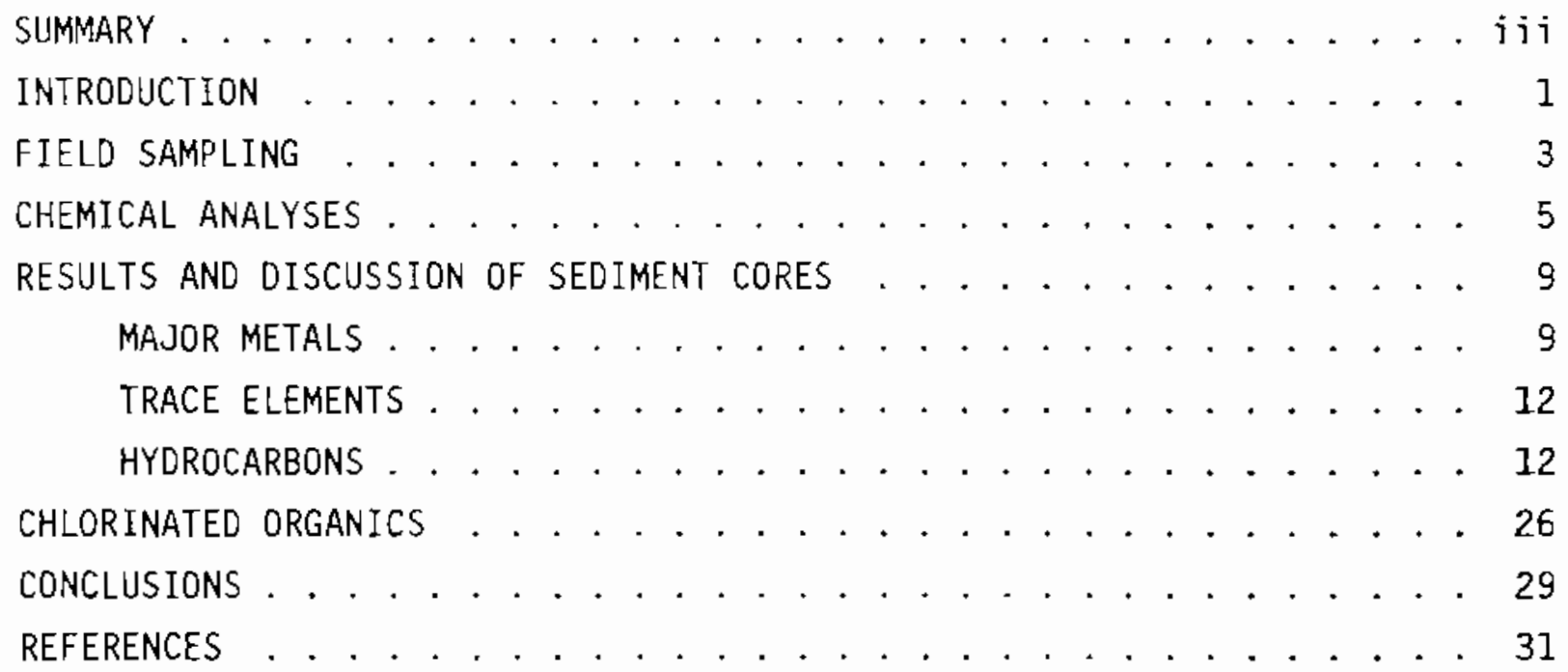




\section{FIGURES}

1 Locations of Sediment Cores Collected on November 8, 1983, in East Waterway (Everett, WA)................. 4

2 Profiles of Mercury ( $\mathrm{Hg}$ ) and Cadmium (Cd) Concentrations with Depth in Core 29 . . . . . . . . . . . . . . . . . . . 13

3 Profile of Lead (Pb) Concentration with Depth in Core BPS-29...................... . . 14

4 Profile of Copper (Cu) Concentration with Depth in Core BPS-29... . . . . . . . . . . . . . . . 15

5 Profiles of Mercury $(\mathrm{Hg})$ and Cadmium (Cd) Concentrations with Depth in Core 30 . . . . . . . . . . . . . . . . . . . . 16

6 Profile of Lead (Pb) Concentration with Depth in Core BPS-30. . . . . . . . . . . . . . . . . . . . 17

7 Profile of Copper (Cu) Concentration with Depth in Core BPS-30.. . . . . . . . . . . . . . . . . . 18

8 Concentration of Total Selected Aromatic Hydrocarbons in Sediment Cores . . . . . . . . . . . . . . . . . . . . . . 25

9 Concentration of PCBs as Aroch\}or 1254 in Sediment Cores . . . . 27 


\section{TABLES}

1 Results of Triplicate Analyses of Standard Marine Sediments ............... . . 6

2 Results of Triplicate Analyses for Metals in Two Everett Harbor Sediments . . . . . . . . . . . . . 7

3 Major Metals and Trace Element Content of Core BPS-29, Everett Harbor. . . . . . . . . . . . . . . 10

4 Major Metals and Trace Element Content of Core BPS-30, Everett Harbor . . . . . . . . . . . . . . . . . . . . . 11

5 Concentration of Saturate Hydrocarbons in Sections of Core BPS-29. . . . . . . . . . . . . . . . 19

6 Concentrations of Aromatic Hydrocarbons in Sections of Core BPS-29 ... . . . . . . . . . . . . . 20

7 Concentrations of Aromatic Hydrocarbons in Sections of Core BPS-29... . . . . . . . . . . . . . . 21

8 Concentration of Saturate Hydrocarbons in Sections of Core BPS-30 . . . . . . . . . . . . . . . . . . 22

9 Concentrations of Aromatic Hydrocarbons in Sections of Core BPS-30 . . . . . . . . . . . . . . 23

10 Concentrations of Aromatic Hydrocarbons in Sections of Core BPS-30 . . . . . . . . . . . . . . . 24

11 Concentrations of PCBs as Arochlor 1254 in Sediments $(\mu \mathrm{g} / \mathrm{Kg}$ dry $\mathrm{wt}) \ldots \ldots . \ldots 26$

12 Comparison of the Concentration of Contaminants in East Waterway Surface Sediment $(\mu \mathrm{g} / \mathrm{g}$ dry $w \mathrm{t}) . . . . . .29$ 
v

• 
CHEMICAL ANALYSIS OF SEDIMENT CORES

FROM THE EAST WATERWAY (EVERETT, WASHINGTON)

\section{INTRODUCTION}

The Seattle District, U.S. Army Corps of Engineers is conducting a general investigation study for improvements to navigation for the existing federal project in Everett Harbor, Washington. The improvement focuses on deepening the East Waterway from its currentiy authorized -30 feet mean lower low water (MLLW) to a depth between -35 and -45 feet MLLW. Previous studies conducted by the National Oceanic and Atmospheric Administration (NOAA) indicate that surface sediments in the East Waterway are chemically contaminated (Malins et al. 1982). Sediment bioassays conducted by the U.S. Environmental Protection Agency (EPA) Region $X$ have determined that sediments in the East Waterway are toxic to amphipods. The EPA is presentiy conducting additional sediment toxicity bioassays and chemical analyses on sediments from the Everett area. The work reported here is a subcomponent of the larger study funded by EPA. Other reports that have addressed water quality in Everett included one by the Washington State Department of Ecology (Singleton et al. 1982) and one by the EPA (1983). Currentiy no data exist regarding the deeper sediments from this harbor.

The principal objective of the work reported here was to determine the extent of chemical contamination at depth compared to surface sediment in the East Waterway. These data will be used to assist in the evaluation of methods for disposing of dredged material. 



\section{FIELD SAMPLING}

Sediment cores were collected in duplicate at two locations (Stations BPS-29 and BPS-30) in the East Waterway on November 8, 1983 (Figure 1). Latitude, longitude, water depth (referenced to mean lower low water $[M L L W]$ ) and core length are listed below:

\begin{tabular}{lcc} 
& \multicolumn{1}{c}{ BPS-29 } & BPS-30 \\
\cline { 2 - 3 } Latitude & $47^{\circ} 59.0^{\prime} \mathrm{N}$ & $47^{\circ} 59.2^{\prime} \mathrm{N}$ \\
Longjtude & $122^{\circ} 13.36 \mathrm{~W}$ & $122^{\circ} 13.2 \mathrm{~W}$ \\
Water depth & $14 \mathrm{~m}$ & $9.8 \mathrm{~m}$ \\
Core length & $110 \mathrm{~cm}$ & $150 \mathrm{~cm}$
\end{tabular}

One core from each station was sectioned for chemical analysis. The other core was sectioned and stored for back up. The cores were collected using a Jarge diameter Kasten-type gravity corer. The cross section of the barrel was $15 \times 15 \mathrm{~cm}$. 


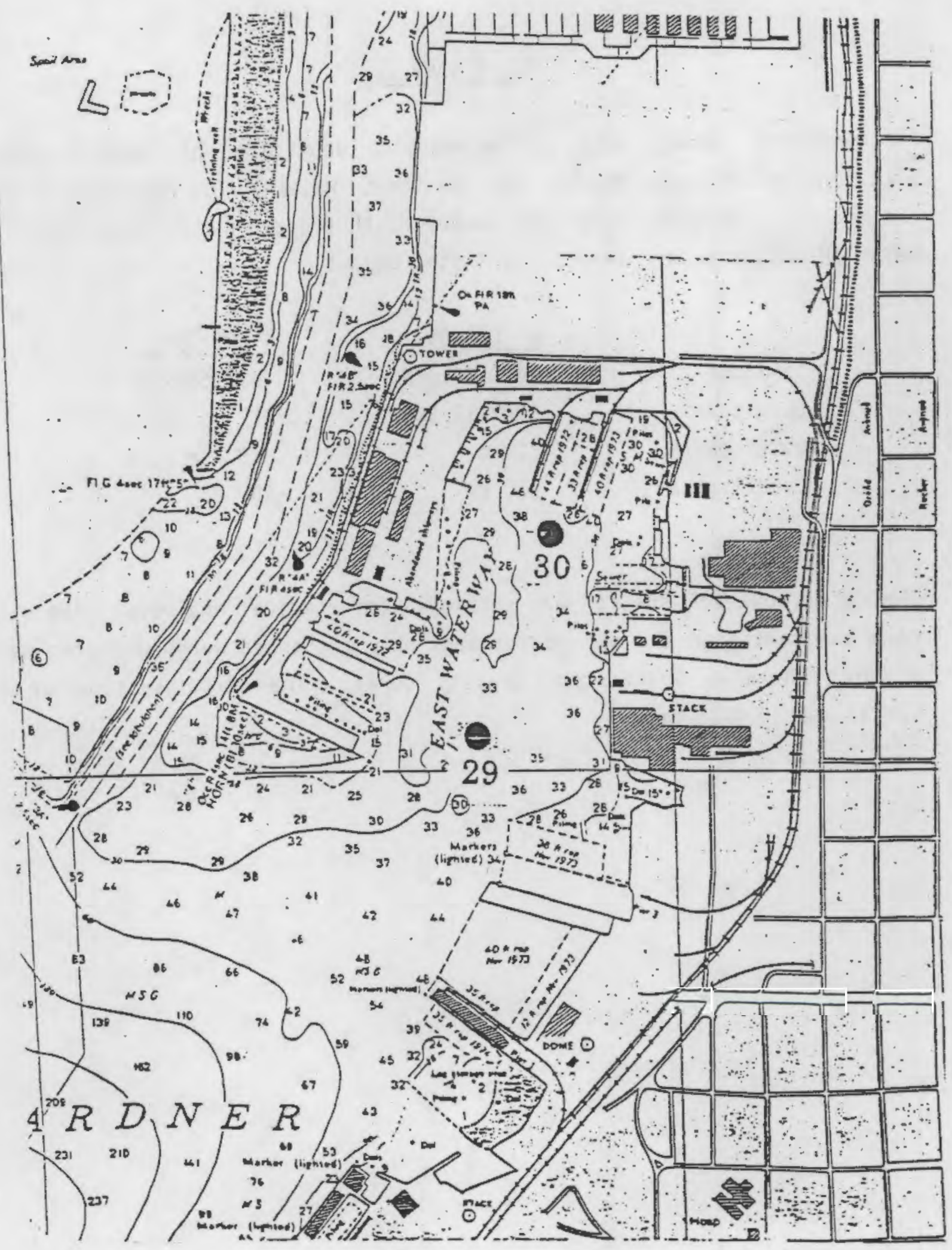

FIGURE 1. Locations of Sediment Cores Collected on November 8, 1983, in East Waterway (Everett. WA) 


\section{CHEMICAL ANALYSES}

The methods for chemical analyses were described in detail by Riley et al. 1980, 1981 and Crecelius et al. (in press) and are summarized here. AII concentrations are reported on a salt-free, dry-weight basis. Selected petroleum hydrocarbons that were quantified include 20 saturate hydrocarbons with carbon numbers from $C_{12}$ to $C_{31}$ and 18 aromatic hydrocarbon components. Six sediment samples were analyzed for several chlorinated organic compounds including polychlorinated biphenyls (PCBs) and chlorinated butadienes (CBDs). For organic chemical analysis, the sediments were soxhlet extracted, subjected to column chromatographic fractionation and the isolated fractions subjected to capillary column gas chromatographic analysis. Inorganic analysis was by either energy dispersive $X$-ray fluorescence or atomic absorption.

To ensure the quality of the chemical analyses, three sediment standards were analyzed for inorganic elements and our results compared to certified values for these standards (Table 1). Also, for the determination of precision of replicate analyses of homogenized sediment two sediment samples from Everett were analyzed in triplicate. The results from triplicate analyses are shown in Table 2. 
TABLE 1. Resuits of Triplicate Analyses of Standard Marine Sediments

\begin{tabular}{|c|c|c|c|c|c|c|c|c|c|c|c|c|c|c|c|c|}
\hline \multirow{2}{*}{$\begin{array}{l}\text { Sediment } \\
\text { Standard }\end{array}$} & \multicolumn{6}{|c|}{ Major Metals, Percent } & \multicolumn{10}{|c|}{ race Elements, Parts per Million } \\
\hline & Al & $\mathrm{Si}$ & $k$ & $\mathrm{Ca}$ & $\mathrm{Ti}$ & $\mathrm{Fe}$ & $\mathrm{Hn}$ & $\mathrm{Cr}$ & $\mathrm{Ni}$ & $\mathrm{Cu}$ & $\mathrm{Zn}$ & $\mathrm{Hg}$ & $\mathrm{Ag}$ & $\mathrm{Co}$ & $\mathrm{Pb}$ & As \\
\hline ESS & .6 & 27.8 & 1.91 & 0.52 & 485 & 3.0 & 452 & 68 & 30.8 & 20.7 & 172 & 0,171 & 0.101 & 0.685 & 33.4 & 10.6 \\
\hline rine mud) & & & 1 . & 0. & & & & 93 & & 22.3 & 1 & & & & & 7.9 \\
\hline & & & 1.8 & 0.49 & 3 & 2. & & 83 & 33.3 & 21 & & & & & & 9. \\
\hline & 5. & 27.8 & 1. 90 & 0.51 & 9 & 2. & 444 & 83 & 31.2 & 21 & 1 & & & & & 9. \\
\hline & & 0.5 & 0.01 & 0.02 & 3 & 0. & 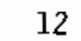 & 15 & 1.9 & & & & 0.009 & & & 1. \\
\hline Cer & & 31.6 & 1. & 0.48 & 3 & 3. & 513 & 71 & 29.5 & 25.1 & 191 & & (b) & & 34.0 & $=0.6$ \\
\hline 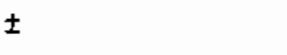 & & 1.0 & 0.0 & 0.04 & 0. & 0 & 25 & 11 & 2.7 & 3.8 & 17 & 0.014 & & 0 & 6.1 & 1.2 \\
\hline & & $c$ & & 0. & & & & 136 & 5 & & & & & & & 0 \\
\hline . & & & & & & & & & & & & & & & & 2. \\
\hline & 6. & 26 & 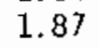 & c & & & & 119 & 5 & & & & & & & in \\
\hline & 5. & 27.3 & 1 & 0 & & 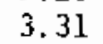 & 200 & 124 & 57.3 & 15 & 106 & & & & & 11. \\
\hline & U. & 0.4 & & & & & 6 & 11 & 77 & & 0.6 & & & & & 0 \\
\hline Cer & 6. & 30.9 & 0 & 0.54 & 0 & 3. & 229 & 123 & 55.3 & 18.5 & 119 & & (b) & & 22.7 & 11.1 \\
\hline & $?$ & 0.5 & 0.03 & 0.05 & 0.013 & 0 & 15 & 14 & 3.6 & 27 & 1. & 0.012 & & 0 & 3.4 & 1.4 \\
\hline 5 & 3 & 2 & 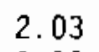 & 0.8 & & & & 6 & 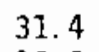 & & & & & & & 10.8 \\
\hline & & & & 0.83 & & & & 80 & & & & & & & & 10. \\
\hline & & & 2.01 & 0.82 & & & & 70 & & & & & & & & 9. \\
\hline & 5.8 & 28.0 & 2.01 & 0.84 & & & 310 & 73 & 33. & 14 & 122 & & & & 25.8 & 10.1 \\
\hline & 0.5 & 0. & & 0.02 & & 0. & 8 & 6 & 2. & 0.8 & 3 & & & & & 0.8 \\
\hline t & 6.3 & (b) & (b) & 0.83 & (b) & 3.3 & 375 & 76 & 32 & 18 & 138 & 0. & (b) & & 28.2 & 11.6 \\
\hline & 0.2 & & & 0.03 & & 0.10 & 20 & 3 & $J$ & $J$ & 6 & 0.012 & & 0.07 & 1.8 & 1.3 \\
\hline
\end{tabular}

(a) Standards MESS-1 and BCSS-1 were provided by the National Research Couneil of Canada. Standard NBS-1646 was provided by the U.S. National Bureau of Standards. $x=$ mean of triplicate analyses reported for this study; $S=$ one standard deviation, certified value for standard; $\pm=$ one standard deviation about the certified value.

(b) Not certified for these elements. 
TABLE 2. Results of Triplicate Analyses for Metals in Two Everett Harbor Sediments

\begin{tabular}{|c|c|c|c|c|c|c|c|c|c|c|c|c|c|c|c|c|}
\hline \multirow{2}{*}{$\begin{array}{l}\text { Sediment } \\
\text { Sample(a) } \\
\text { (Core \& } \\
\text { Depth) }\end{array}$} & \multicolumn{6}{|c|}{ Major Metals, Percent ${ }^{(b)}$} & \multicolumn{10}{|c|}{ Trace Elements, Parts per Million ${ }^{(b)}$} \\
\hline & Al & Si & k & Ca & $\mathrm{Ti}$ & $\mathrm{Fe}$ & Mn & $\mathrm{Cr}$ & $\mathrm{Ni}$ & $\mathrm{Cu}$ & Zn & $\mathrm{Hg}$ & $\mathrm{Ag}$ & $\mathrm{Cd}$ & $\mathrm{Pb}$ & As \\
\hline BPS- 2 & 4.9 & 16.7 & 0.94 & 1.54 & 0.314 & 3.14 & 392 & 116 & 55.2 & 75.6 & 200 & 0.180 & 0.383 & 2.53 & 55.7 & \\
\hline $20-$ & 4.3 & 16.3 & 0.93 & 1.43 & 0.302 & 3.08 & 386 & 107 & 56.4 & 75.7 & 172 & 0.175 & 0.589 & 2.40 & 44.9 & \\
\hline & 4.8 & 16.6 & 0.91 & 1.52 & 0.301 & 3. & 381 & 300 & 59.9 & 77.8 & 171 & 0.170 & 0.366 & 2.53 & 45.2 & 10 \\
\hline$x$ & 4.7 & 16.5 & 0.33 & 1.50 & 0.306 & 3.09 & 386 & 108 & 57.2 & 76.3 & 181 & 0.175 & 0.446 & 2.49 & 48.6 & 12 \\
\hline$s$ & 0.3 & 0.2 & 0.02 & 0.06 & 0.007 & 0. & 6 & 8 & 2.4 & 1.2 & 16 & 0.005 & 0.124 & 0.08 & 6.2 & \\
\hline $\operatorname{RSD}(\%)$ & 6.8 & 1.3 & 1.6 & 3.9 & 2.4 & 1.4 & 1.4 & 7.4 & 4.3 & 1.6 & 9.1 & 2.9 & 27.8 & 3.0 & 12.7 & 19 \\
\hline BPS & 6.9 & 26.0 & 1.21 & 1.95 & 0.465 & 4. & 615 & 13 & 70.4 & 54.8 & 94.7 & & & 0.477 & & \\
\hline 135 & 7 & 26.5 & 1.24 & 1.92 & 0.475 & 4. & 578 & 16 & & & & & & & & \\
\hline & 7.5 & 26.4 & 1.24 & 1.93 & 0.471 & 4.45 & 609 & 158 & 69.9 & 51.6 & 98.6 & 0.090 & 0. & 0.494 & 12.7 & \\
\hline ก & 7.2 & 26.3 & 1.23 & 1.93 & 0.470 & 4.44 & 601 & 152 & 71.3 & 52 & 97.2 & 0.098 & 0.112 & 0.487 & 13.1 & 11 \\
\hline & 0.3 & 0.3 & 0.02 & 0.02 & 0.005 & .0 .02 & 20 & 15 & 1.7 & 1.8 & 2.2 & 0.009 & 0.010 & 0.009 & 0.9 & 0 \\
\hline $\operatorname{RSD}(\%)$ & 4.2 & 1.0 & 1.4 & 0.8 & 1.1 & 0.4 & 3.3 & 9.6 & 2.4 & 3.4 & 2.2 & 9.4 & 9.1 & 1.9 & 6.7 & \\
\hline
\end{tabular}

(a) $\bar{x}=$ mean of three analyses of ane homogenious sample; $S=$ one standard deviation; $R S D(\mathscr{X})=$ percent relative standard deviation.

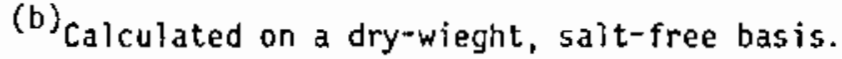





\section{RESULTS AND DISCUSSION OF SEDIMENT CORES}

The sediments cored in the East Waterway were primarily a mixture of poorly consolidated sand, mud, wood chips and tree bark. However the bottom of each core contained compact mud, indicating the core barrel had penetrated through the sediments that have accumulated since the East Waterway was dredged. The sediments, except for the botton two sections, were black in color, contained hydrogen sulfide gas and smelled of petroleum. The sources of the wood chips and bark are the wood products industries and $\log$ boom storage area in East Waterway. The chemical and physical properties of the sediments indicate the lengths of the cores, $110 \mathrm{~cm}$ for Core 29 and $150 \mathrm{~cm}$ for Core 30, were long enough to penetrate through the sediments deposited since the waterway was dredged. The sedimentation rate in the East waterway ranges from 20 to $30 \mathrm{~cm}$ per year assuming 100 to $150 \mathrm{~cm}$ of sediment has accumulated in the last 5 years. According to dredging records (personal communication with Steven Dice, U.S. Army Corps of Engineers, Seattle 0istrict) the East Waterway was last maintenance dredged by the Corps in 1978 under contract DACW67-78-C-0081. This dredging was completed on October 9, 1978. Under that contract the East Waterway navigation channel was dredged to -34 feet MLLW.

\section{MAJOR METALS}

The concentrations of major metals and trace elements in sections of the cores are shown in Tables 3 and 4 . The concentrations of the major metals are typical of fine-grained marine sediment. These concentrations generally increase with depth in the cores, probably due to dilution of the sediment with wood chips and bark. The greatest change in these metais occurs in the bottom section of Core 29 and the bottom two sections of Core 30. These three sections were gray in color and did not contain wood and bark. Also, the sediment density was much greater than the less consolidated sediments above. 
IABLE 3. Major Metals and Trace Eiement Content of Core BPS-29, (a) Everett Harbor

\begin{tabular}{|c|c|c|c|c|c|c|c|c|c|c|c|c|c|c|c|c|}
\hline \multirow[b]{2}{*}{$\begin{array}{l}\text { Depth, } \\
\text { cm }\end{array}$} & \multicolumn{6}{|c|}{ Major Metais, Percent ${ }^{(b)}$} & \multicolumn{10}{|c|}{ Trace Elements, Parts per Million (b) } \\
\hline & A] & Si & $k$ & $\mathrm{Ca}$ & $\mathrm{Ti}$ & $\mathrm{Fe}$ & Mn & $\mathrm{Cr}$ & $\mathrm{Ni}$ & $\mathrm{Cu}$ & $2 n$ & $\mathrm{Hg}$ & $\mathrm{Ag}$ & $\mathrm{Cd}$ & $\mathrm{Pb}$ & As \\
\hline $\begin{array}{l}0-5 \\
5-10\end{array}$ & 5.0 & 17.5 & 1.00 & 1.57 & 0.322 & 3.33 & 418 & 98 & 57.2 & 70.7 & 221 & $\begin{array}{l}0.177 \\
0.207\end{array}$ & $\begin{array}{l}0.392 \\
0.403\end{array}$ & $\begin{array}{l}2.37 \\
2.39\end{array}$ & $\begin{array}{l}40.2 \\
34.1\end{array}$ & 13.2 \\
\hline $\begin{array}{l}10-15 \\
15-20\end{array}$ & 5.5 & 17.8 & 0.94 & 1.52 & 0.303 & 3.27 & 427 & 126 & 57.3 & 71.2 & 182 & $\begin{array}{l}0.207 \\
0.188 \\
0.288\end{array}$ & 0.372 & 2.26 & 40.4 & 13.0 \\
\hline $\begin{array}{l}20-25(c) \\
25-30\end{array}$ & 4.7 & 16.5 & 0.93 & 1.50 & 0.306 & 3.09 & 386 & 108 & 57.2 & 76.3 & 181 & $\begin{array}{l}0.175 \\
0.232\end{array}$ & $\begin{array}{l}0.446 \\
0.416\end{array}$ & $\begin{array}{l}2.49 \\
2.37\end{array}$ & $\begin{array}{l}40.0 \\
48.6 \\
45.7\end{array}$ & 12.0 \\
\hline $\begin{array}{l}30-35 \\
35-40\end{array}$ & 4.5 & 18.6 & 0.98 & 1.65 & 0.307 & 3.14 & 412 & 101 & 59.5 & 72.4 & 127 & $\begin{array}{l}0.235 \\
0.163\end{array}$ & $\begin{array}{l}0.352 \\
0.285\end{array}$ & $\begin{array}{l}2.22 \\
1.73\end{array}$ & $\begin{array}{l}46.7 \\
35.1\end{array}$ & 6.1 \\
\hline $\begin{array}{l}40-45 \\
45-50\end{array}$ & 5.0 & 20.1 & 0.92 & 2.17 & 0.282 & 3.20 & 419 & 107 & 52.5 & 60.5 & 93 & $\begin{array}{l}0.205 \\
0.383\end{array}$ & $\begin{array}{l}0.243 \\
0.336\end{array}$ & $\begin{array}{l}1.62 \\
1.93\end{array}$ & $\begin{array}{l}35.3 \\
44.7\end{array}$ & 6.3 \\
\hline $\begin{array}{l}50-55 \\
55-60\end{array}$ & 6.6 & 21.9 & 1.06 & 1.80 & 0.364 & 3.35 & 480 & 121 & 59.9 & 90.1 & 125 & $\begin{array}{l}0.767 \\
0.533\end{array}$ & $\begin{array}{l}0.327 \\
0.249\end{array}$ & $\begin{array}{l}1.86 \\
1.53\end{array}$ & $\begin{array}{l}55.0 \\
42.4\end{array}$ & 9.1 \\
\hline $\begin{array}{l}60-65 \\
65-70\end{array}$ & 5.9 & 25.5 & 1.14 & 1.96 & 0.381 & 3.59 & 523 & 147 & 56.9 & 87.0 & 110 & $\begin{array}{l}0.804 \\
0.153\end{array}$ & $\begin{array}{l}0.238 \\
0.178\end{array}$ & $\begin{array}{l}1.49 \\
0.755\end{array}$ & $\begin{array}{l}45.2 \\
16.1\end{array}$ & 10.5 \\
\hline $\begin{array}{l}70-75 \\
75-80 \\
80-85\end{array}$ & 6.5 & 24.2 & 1.29 & 1.80 & 0.456 & 4.43 & 582 & 158 & 71.7 & 75.6 & 119 & $\begin{array}{l}0.201 \\
0.220\end{array}$ & $\begin{array}{l}0.203 \\
0.225\end{array}$ & $\begin{array}{l}1.15 \\
1.17\end{array}$ & $\begin{array}{l}26.1 \\
29.7\end{array}$ & 11.9 \\
\hline $\begin{array}{c}90-95 \\
100-105\end{array}$ & 7.4 & 23.5 & 1.28 & 1.76 & 0.451 & 4.57 & 579 & 155 & 78.2 & 82.8 & 124 & $\begin{array}{l}0.142 \\
0.198 \\
0.757\end{array}$ & $\begin{array}{l}0.215 \\
0.253\end{array}$ & $\begin{array}{l}0.909 \\
1.05\end{array}$ & $\begin{array}{l}20.7 \\
29.2\end{array}$ & 14.0 \\
\hline $105-110$ & 8.3 & 22.8 & 1.44 & 1.64 & 0.531 & 5.98 & 699 & 192 & 97.9 & 87.5 & 133 & $\begin{array}{l}0.157 \\
0.121\end{array}$ & $\begin{array}{l}0.232 \\
0.221\end{array}$ & $\begin{array}{l}0.673 \\
0.592\end{array}$ & $\begin{array}{l}16.7 \\
17.5\end{array}$ & 16.5 \\
\hline
\end{tabular}

(a) Latitude $47^{\circ} 59.0^{\prime} \mathrm{N}$, longitude $122^{\circ} 13.3 \mathrm{6W}$; water depth $14 \mathrm{~m}$; Datum $\mathrm{MLLW}$; core length $110 \mathrm{~cm}$, date 11-8-83.

(b) Calculated on a dry-weight, salt-free basis.

(c) Represents the mean of a triplicate analysis. 
IABLE 4. Major Metals and Trace Element Content of Core BPS-30, (a) Everett Harbor

\begin{tabular}{|c|c|c|c|c|c|c|c|c|c|c|c|c|c|c|c|c|}
\hline \multirow[b]{2}{*}{$\begin{array}{l}\text { Depth, } \\
\quad \mathrm{cm}\end{array}$} & \multicolumn{6}{|c|}{ Major Metals, Percent ${ }^{(b)}$} & \multicolumn{10}{|c|}{ Trace Elements, Parts per Million(b) } \\
\hline & A) & Si & k & Ca & $T i$ & $\mathrm{Fe}$ & Mn & $\mathrm{Cr}$ & $\mathrm{Ni}$ & $\mathrm{Cu}$ & $2 n$ & $\mathrm{Hg}$ & $\mathrm{Ag}$ & $\mathrm{Cd}$ & $\mathrm{Pb}$ & As \\
\hline $\begin{array}{l}0-5 \\
5-10\end{array}$ & 6.1 & 20.8 & 1.20 & 1.77 & 0.372 & 3.85 & 518 & 148 & 69.4 & 89.5 & 365 & $\begin{array}{l}0.213 \\
0.210\end{array}$ & $\begin{array}{l}0.537 \\
0.594\end{array}$ & $\begin{array}{l}4.63 \\
4.73\end{array}$ & $\begin{array}{l}55.5 \\
52.4\end{array}$ & 15.2 \\
\hline $\begin{array}{l}10-15 \\
15-20\end{array}$ & 5.3 & 20.2 & 1.16 & 1.67 & 0.364 & 3.86 & 506 & 132 & 68.9 & 89.3 & 344 & 0.174 & 0.580 & 4.27 & 57.4 & 10.2 \\
\hline $\begin{array}{l}15-20 \\
20-25\end{array}$ & 5.6 & 20.5 & 1.07 & 1.61 & 0.359 & 3.69 & 470 & 120 & 64.8 & 90.3 & 229 & $\begin{array}{l}0.325 \\
0.276\end{array}$ & $\begin{array}{l}0.643 \\
0.562\end{array}$ & $\begin{array}{l}3.79 \\
2.85\end{array}$ & $\begin{array}{l}53.8 \\
61.9\end{array}$ & 6.6 \\
\hline $25-30$ & & & & & & & & & & 50.5 & 203 & 0.263 & 0.339 & 1.77 & 48.3 & 0.0 \\
\hline $\begin{array}{l}30-35 \\
35-40\end{array}$ & 6.3 & 23.3 & 1.11 & 1.87 & 0.397 & 3.99 & 513 & 142 & 67.3 & 78.9 & 184 & $\begin{array}{l}0.432 \\
0.371\end{array}$ & $\begin{array}{l}0.297 \\
0.366\end{array}$ & $\begin{array}{l}1.58 \\
2.10\end{array}$ & $\begin{array}{l}76.1 \\
48.9\end{array}$ & 5.8 \\
\hline $45-50$ & & & & & & & & & & & & 0.278 & 0.706 & 3.44 & 73.3 & \\
\hline $\begin{array}{l}55-60 \\
65-70\end{array}$ & 5.3 & 21.2 & 1.08 & 1.53 & 0.355 & 3.74 & 467 & 122 & 68.2 & 96.7 & 183 & $\begin{array}{l}0.324 \\
0.315\end{array}$ & $\begin{array}{l}0.781 \\
0.443\end{array}$ & $\begin{array}{l}3.51 \\
1.60\end{array}$ & $\begin{array}{l}74.8 \\
72.7\end{array}$ & 5.3 \\
\hline $75-80$ & & & & & & & & & & & & 0.791 & 0.605 & 2.59 & 91.2 & \\
\hline $\begin{array}{l}85-90 \\
95-100\end{array}$ & 5.7 & 18.6 & 1.04 & 1.57 & 0.329 & 3.67 & 462 & 125 & 68.5 & 156.6 & 182 & $\begin{array}{l}0.727 \\
1.80\end{array}$ & $\begin{array}{l}0.713 \\
0.524\end{array}$ & $\begin{array}{l}2.43 \\
2.40\end{array}$ & $\begin{array}{l}92.2 \\
86.2\end{array}$ & 2.7 \\
\hline $100-105$ & 5.0 & 18.5 & 0.96 & 1. 58 & 0.318 & 3.93 & 443 & 108 & 72.8 & 165.3 & 206 & 1.14 & 0.410 & 2.57 & 100.9 & 4.5 \\
\hline $105-110$ & & & & & & & & & & & & 3.01 & 0.290 & 3.25 & 176.9 & \\
\hline $\begin{array}{l}115-120 \\
125-130(c)\end{array}$ & 5.2 & 19.8 & 1.05 & 1.84 & 0.338 & 3.94 & 484 & 118 & 78.6 & 192.9 & 312 & $\begin{array}{l}2.18 \\
1.33\end{array}$ & $\begin{array}{l}0.514 \\
0.512\end{array}$ & $\begin{array}{l}2.53 \\
2.39\end{array}$ & $\begin{array}{l}175.3 \\
122.0\end{array}$ & 4.2 \\
\hline $135-140^{(C)}$ & 7.2 & 26.3 & 1.23 & 1.93 & 0.470 & 4.44 & 597 & 151 & 71.2 & 52.8 & 97 & 0.098 & 0.112 & 0.487 & 13.1 & 11.0 \\
\hline $145-150$ & 7.0 & 26.1 & 1.25 & 1.96 & 0.456 & 4.25 & 585 & 149 & 68.6 & 50.2 & 91 & 0.075 & 0.090 & 0.432 & 13.8 & 10.0 \\
\hline
\end{tabular}

(a) Latitude $47^{\circ} 59.2^{\prime} \mathrm{N}$, longitude $122^{\circ} 13.2 \mathrm{~W}$; water depth $9.8 \mathrm{~m}$; Datum MLLW; core length $150 \mathrm{~cm}$, date $11-8-83$.

(b) Caiculated on a dry-weight, salt-free basis.

(c) Represents the mean of a triplicate analysis. 


\section{TRACE ELEMENTS}

Of the ten trace elements that were analyzed in the cores, $\mathrm{Cu}, \mathrm{Zn}, \mathrm{Hg}$, $\mathrm{Ag}, \mathrm{Cd}$ and $\mathrm{Pb}$ are significantly elevated compared to other sediments deposited in Puget Sound more than 100 years ago (Paviou et a1. 1983). The profiles of concentration with depth of four heavy metals $(\mathrm{Hg}, \mathrm{Cd}, \mathrm{Pb}$ and $\mathrm{Cu})$ in the cores are shown in Figures 2 through 7 . Three conclusions can be made from these data. First, the sediments of East Waterway contain significantly high concentrations of these five heavy metals compared to the bottom of Core 30 . Second, the maximum $\mathrm{Hg}, \mathrm{Pb}$ and $\mathrm{Cu}$ contamination occurs at a depth of 100 to $130 \mathrm{~cm}$ in Core 30 . A subsurface maximum in $\mathrm{Hg}$, $\mathrm{Pb}$ and $\mathrm{Cu}$ is also present at a depth of $60 \mathrm{~cm}$ in Core 29 indicating these metals were probably discharged at a much higher rate in past years than presently in the inner region of East Waterway. Finally, the concentrations of $\mathrm{Cd}$ in surface sediments are higher than at depth, suggesting a different history of contamination for $\mathrm{Cd}$ than for the other metals.

\section{HYDROCARBONS}

Qualitative examination of GC chromatograms of sediment core extracts indicated hydrocarbon patterns that are characteristic of a petroleum distillate. The patterns were similar for both cores. The concentration of 20 saturate hydrocarbons $\left(\mathrm{C}_{12}-\mathrm{C}_{31}\right)$ and 18 aromatic hydrocarobns were determined at 10 depths in each core (Tables 5 through 10). rotal concentrations of aromatic hydrocarbons with sediment depth are depicted in Figure 8. In both cores the concentrations of hydrocarbons increase with depth, reaching a maximum in the lower third of the core, then decreasing to the lowest concentrations in the bottom sections. The subsurface maximum concentrations are three to eight times greater than the hydrocarbon concentrations in the surface sediment. Although core 30 is more heavily contaminated than Core 29 , the similar vertical distributions in both cores suggest sediments from the entire East Waterway have been heavily contaminated with hydrocarbons. Maximum contamination appears to have occurred following the last dredging at these coring stations. rotal 


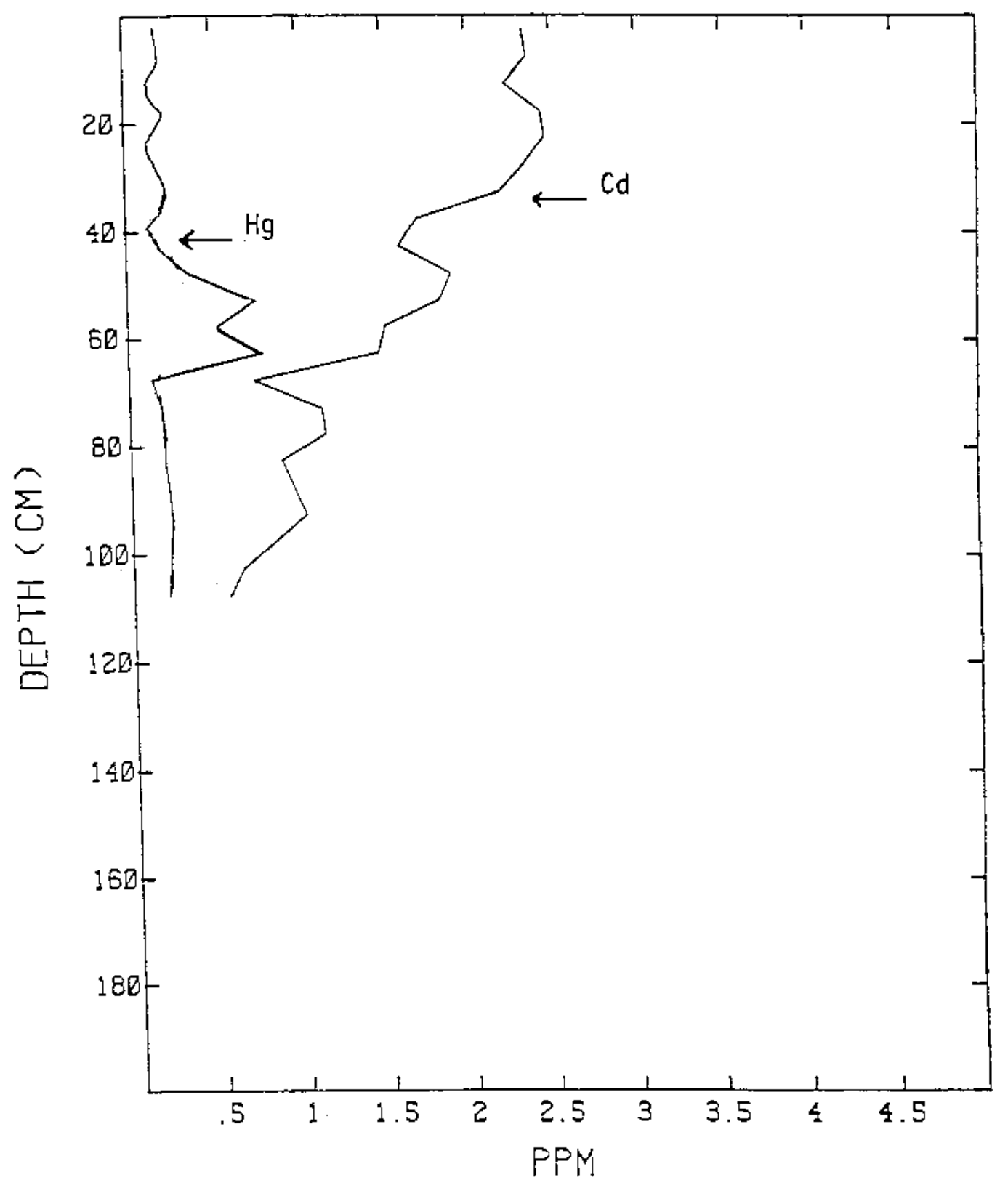

FIGURE 2. Profiles of Mercury ( $H_{g}$ ) and Cadmium (Cd) Concentrations with Depth 


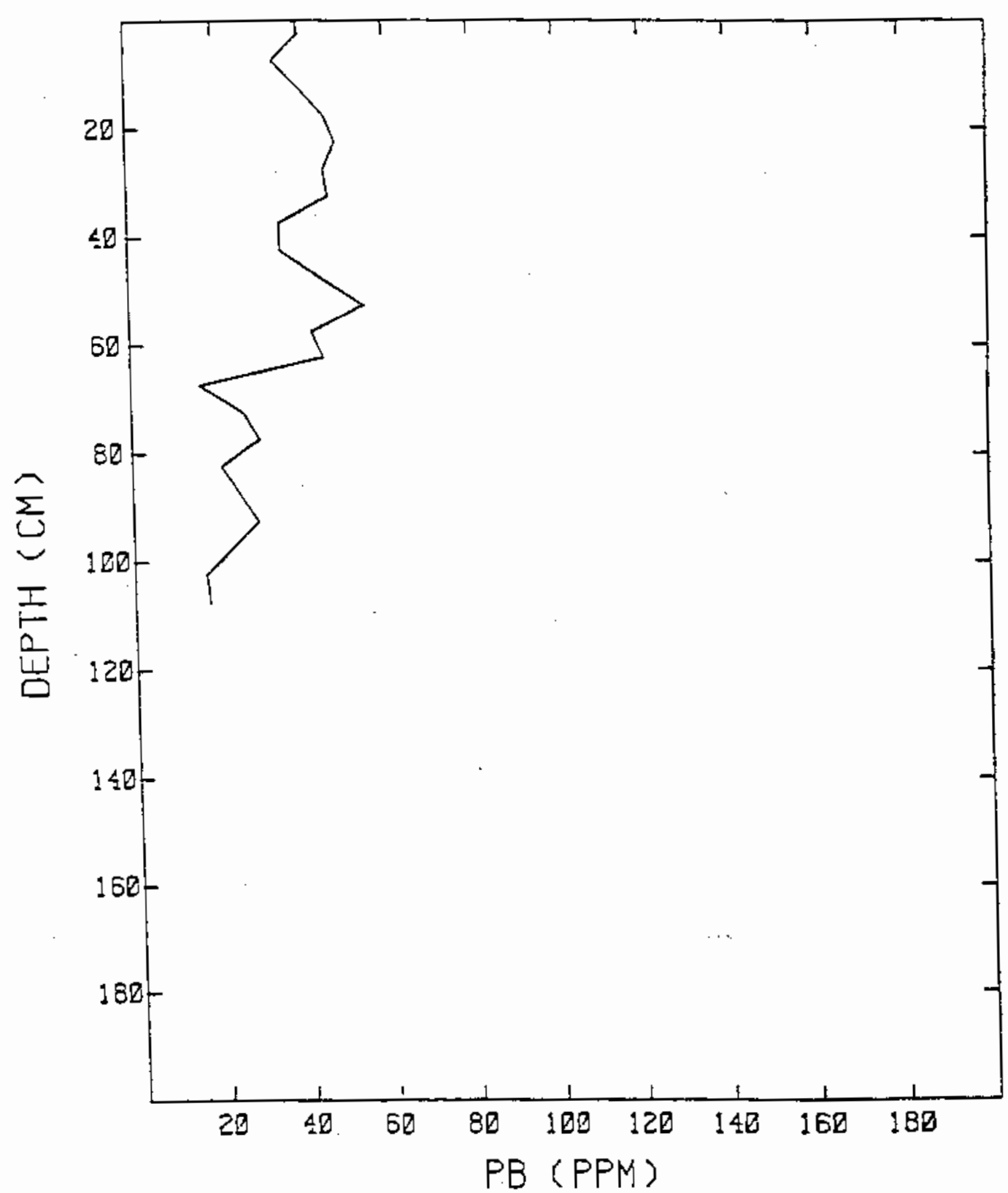

FIGURE 3. Profile of Lead (Pb) Concentration with Depth in Core BPS-29 


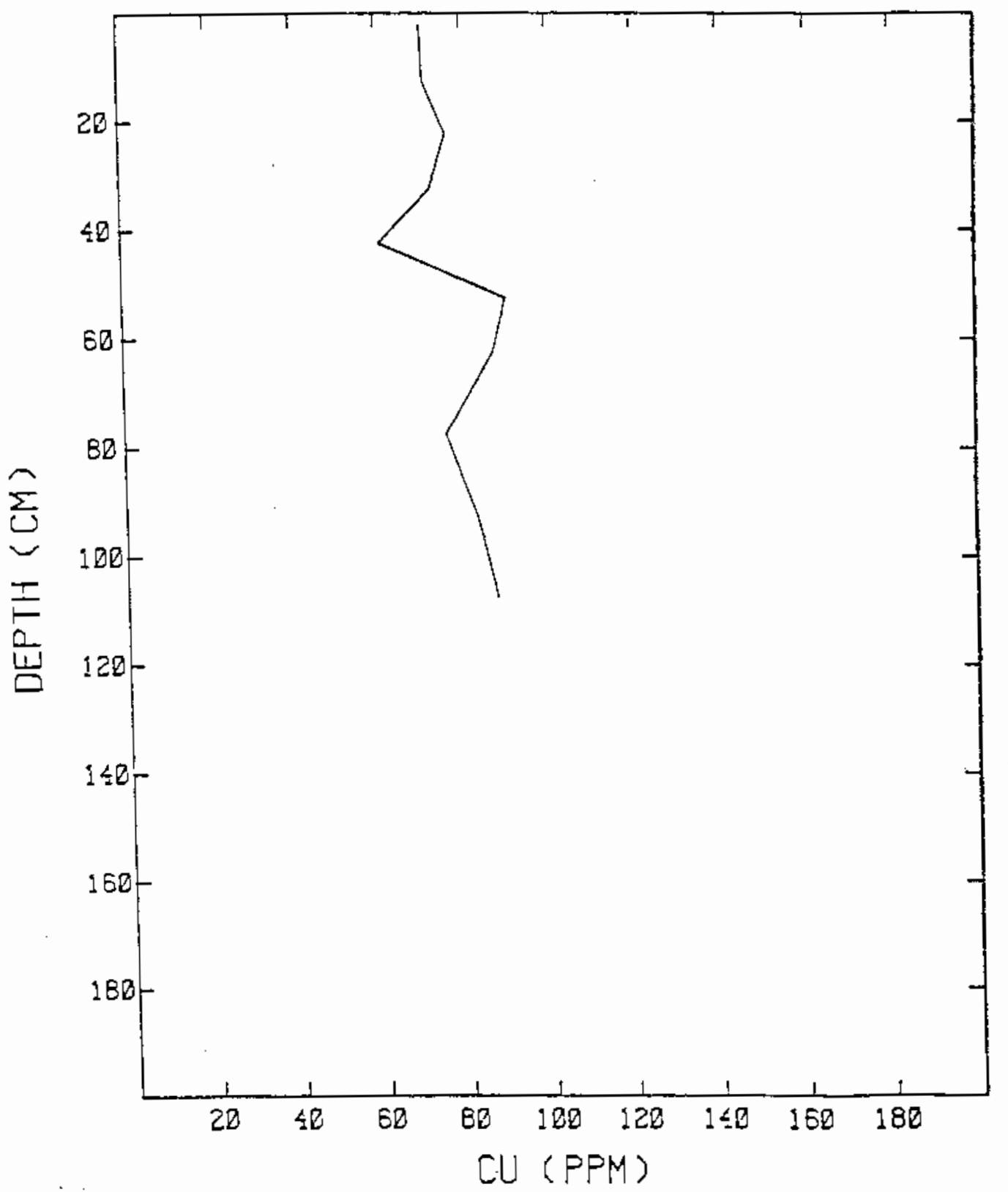

FIGURE 4. Profile of Copper (C!) Concentration with Depth in Core BPS-29 


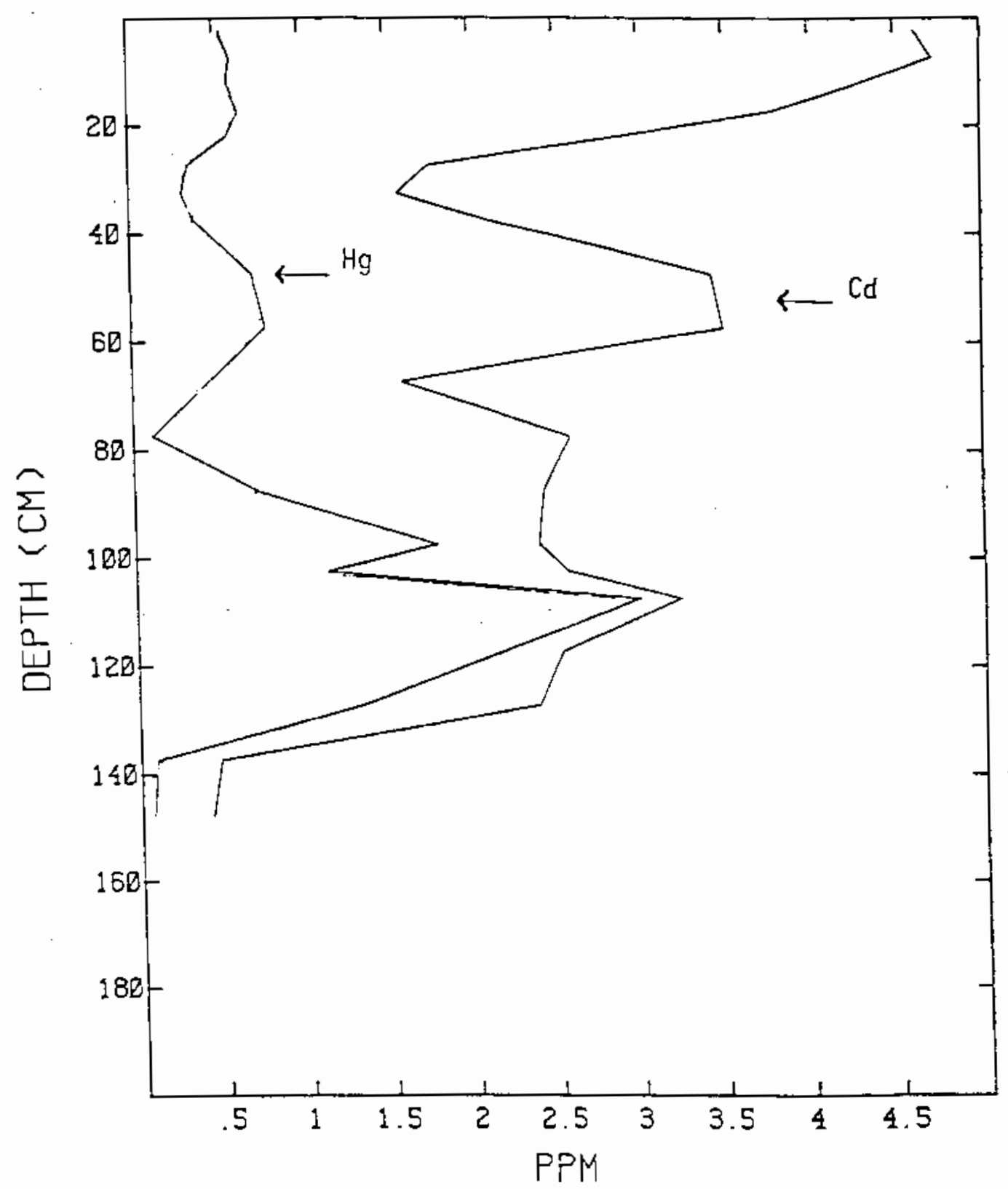

FIGURE 5. Profiies of Mercury ( $\mathrm{Hg}$ ) and Cadmium (Cd) Concentrations with Depth in Core BPS-30 


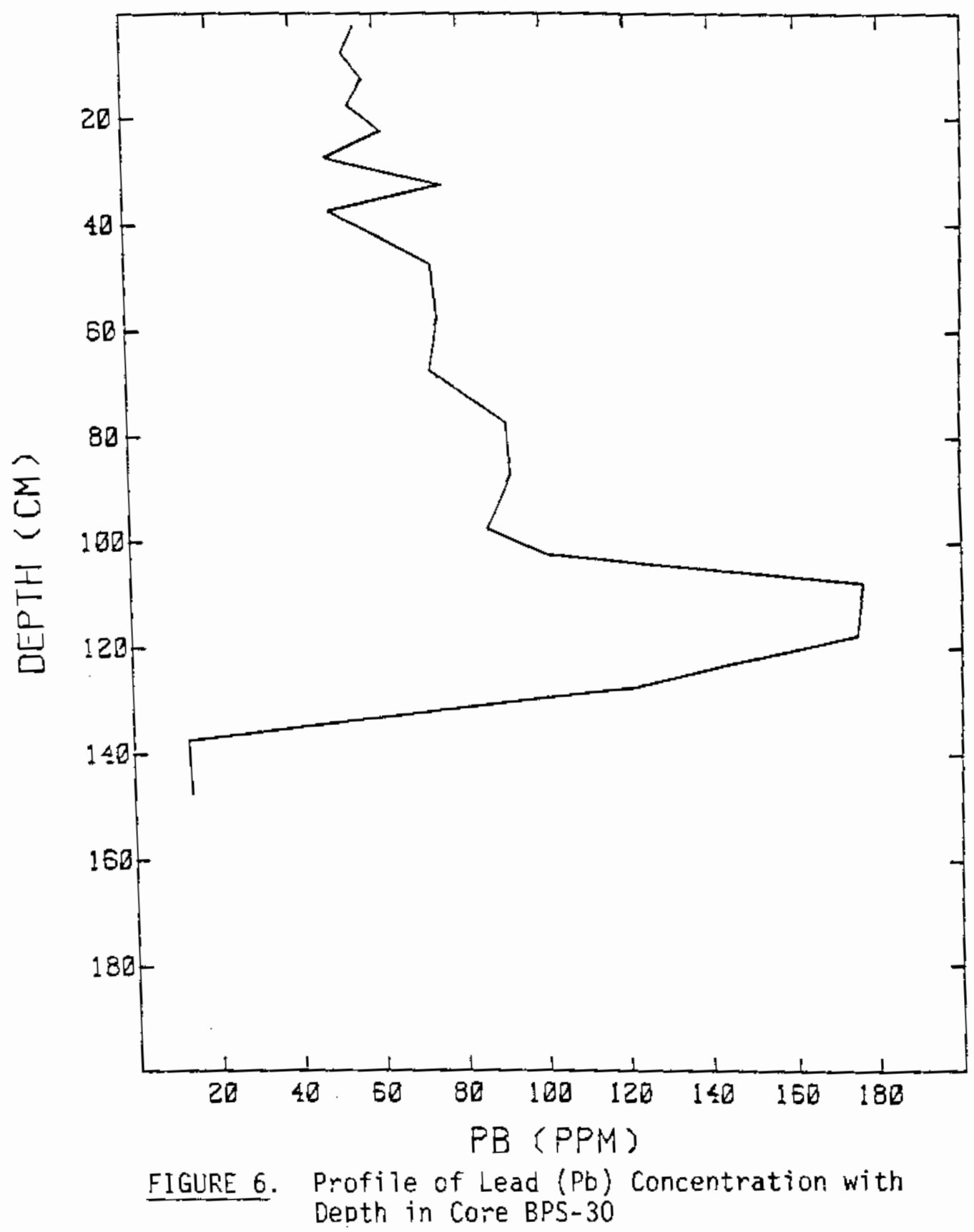




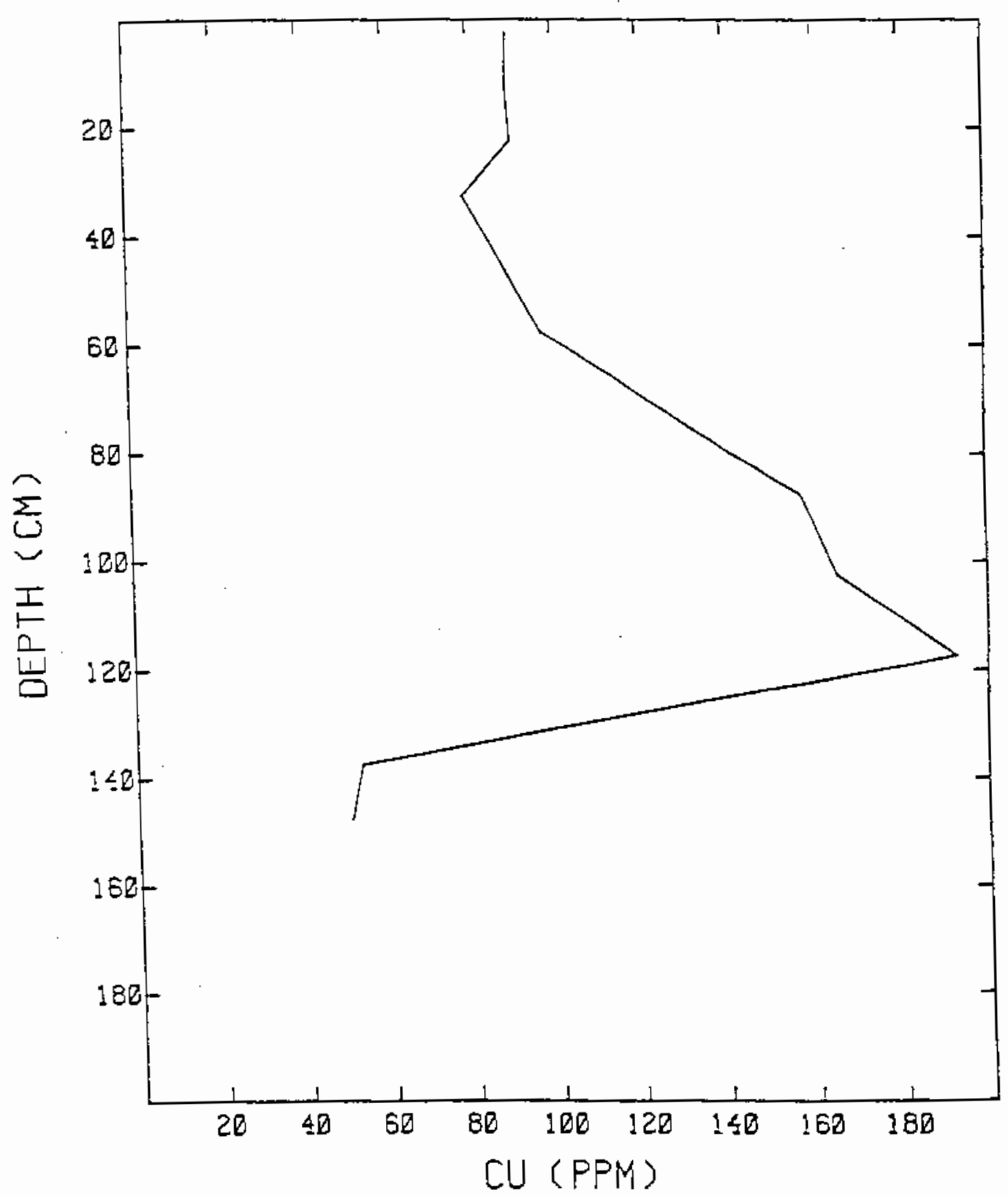

FIGURE 7. Profile of Copper (CU) Concentration with Dpeth in Core BPS-30 
TABLE. 5 . CATURATE COACENTRATION OF SATURATE HYDROCARBONS IN SECTIONS OF CORE BPS-29. CONCENTRATIONS IN MICROGRAMS PER RILOGRAM OF DRY SEDINENT (PPB). FACTOR

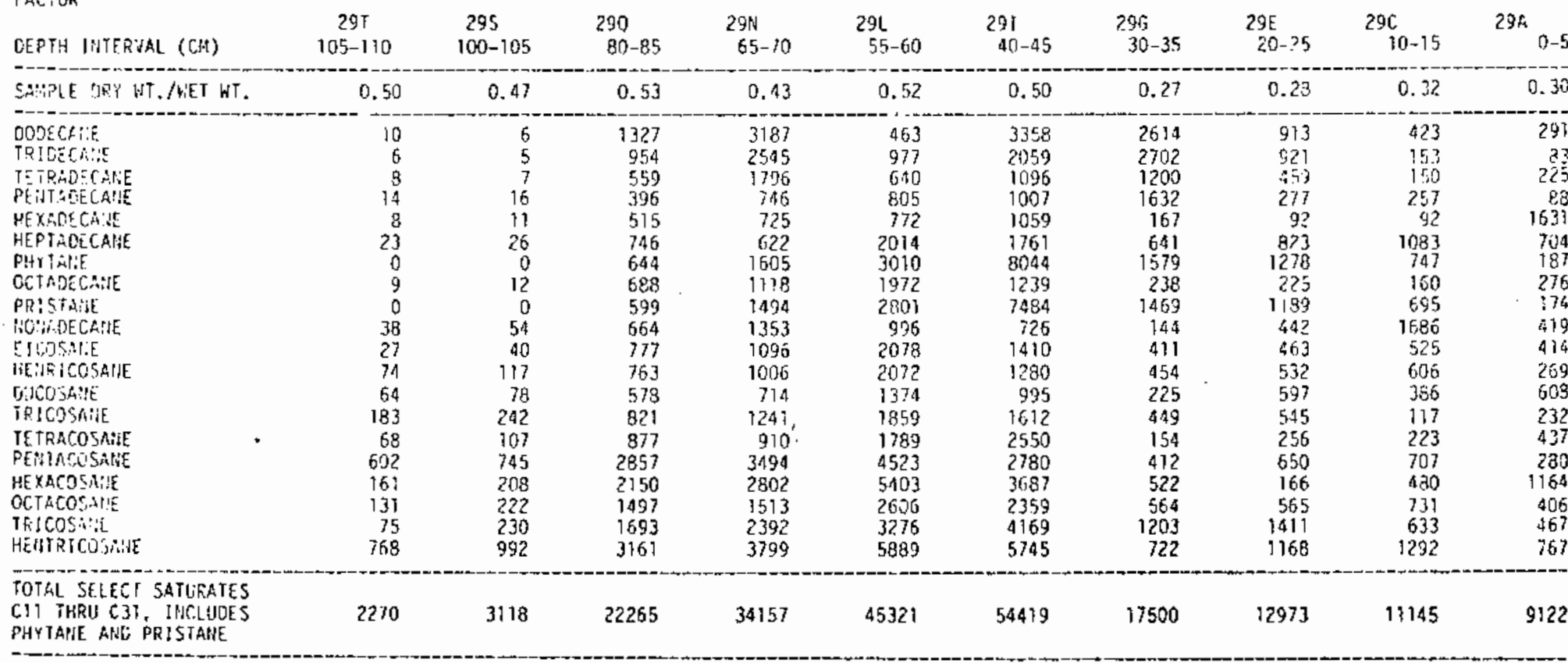


TABLE 6 .

CONCENTRATIONS OF AROMATIC HYDROCARBONS IN SECTIONS OF CORE BPS 29 CONCENTRATIONS ARE IN MICROGRAMS PER KILOGRAM DRY SEDIMENT (PPB).

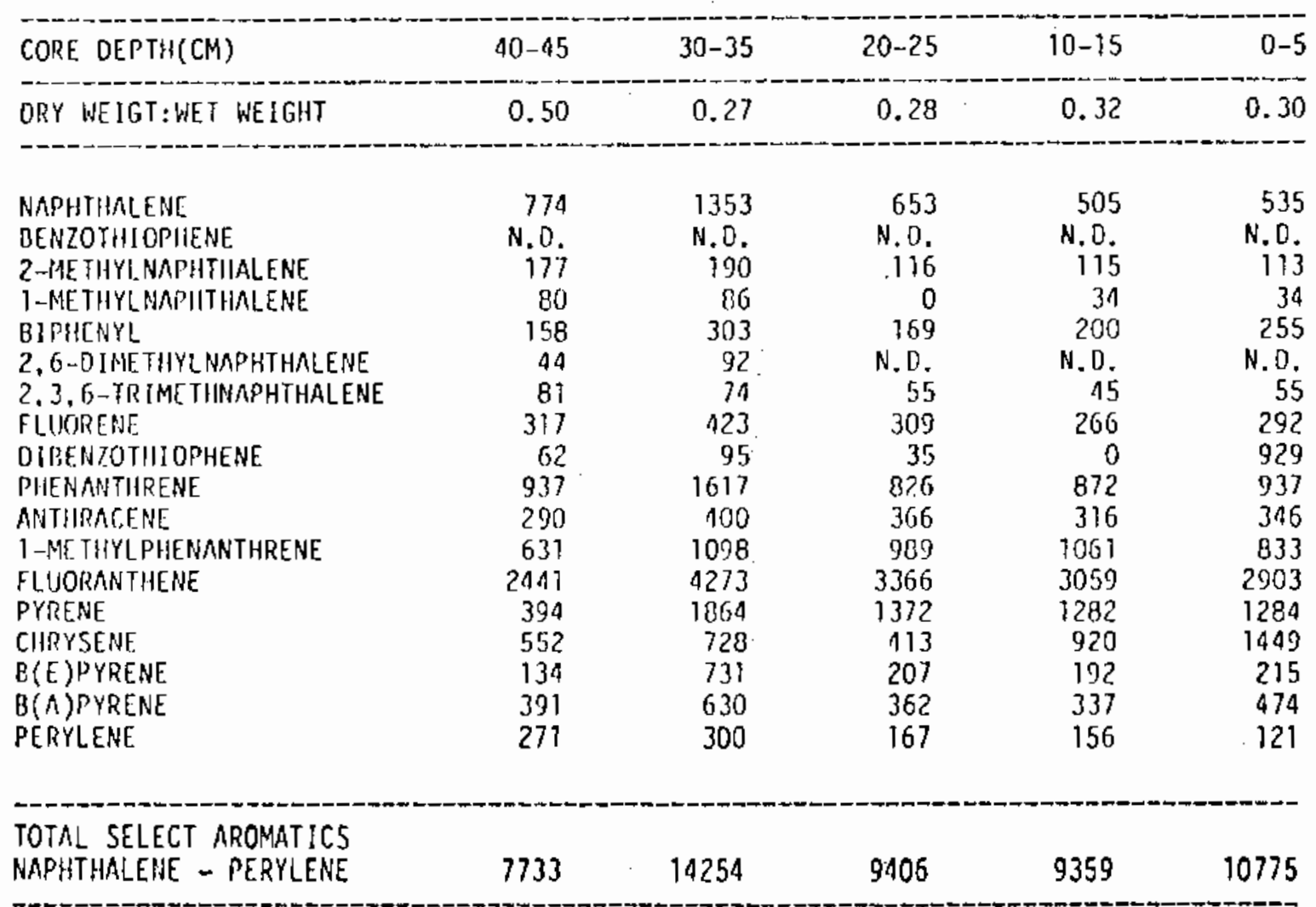

N.D. -CONCENTRATION IS 5 MICROGRAMS/KILOGRAM DRY SEOIMENT. 
IABLE 7.

CONCENTRATIONS OF AROMATIC HYOROCARBONS IN SECTIONS OF CORE BPS 29 CONCENTRATIONS ARE IN MICROGRAMS PER KILOGRAM OF DRY SEDIMENT (PPB).

\begin{tabular}{|c|c|c|c|c|c|}
\hline CORE DEPIH(CM) & $105+110$ & $100-105$ & $80-85$ & $65-70$ & $55-60$ \\
\hline DRY WE IGT: WET WEIGIHT & 0.50 & 0.47 & 0.53 & 0.43 & 0.52 \\
\hline NAPHTIIALENE & 59 & 109 & 865 & 992 & 3212 \\
\hline BENZOTIIIOPIENE & N. 0 & N. 0 & 33 & 48 & 116 \\
\hline 2-NAETHYLNAPIUTHINLENE & 26 & 46 & 195 & 227 & 640 \\
\hline 1-NAETIIYI_NAPPHTHIALENE & 9 & 17 & 101 & T89 & 405 \\
\hline BIPHEHYL & 21 & 24 & 112 & 207 & 360 \\
\hline 2.6-D IME THYL NAPHTHALENE & 14 & 27 & 73 & 116 & 302 \\
\hline $2,3,6$-TR IMETHNAPIITHALENE & 5 & 9 & 81 & 142 & 442 \\
\hline FLHORFNE. & 27 & 54 & 336 & 750 & 1291 \\
\hline DIBENZOTIIIOIPHEAE & N.D. & 10 & 336 & 456 & 1306 \\
\hline PIIENANTHRENE & 126 & 241 & 1213 & 1736 & 4767 \\
\hline AHTHRNCENF. & 40 & 83 & 494 & 1142 & 1749 \\
\hline I-HETHYLPHENANTHRENE & 68 & 85 & $290 \cdot$ & 880 & 2162 \\
\hline FLUORANTHENE & 236 & 406 & 2319 & 4015 & 8233 \\
\hline PYRENE & 160 & 279 & 1321 & 2008 & 4340 \\
\hline CHRYSENE & 103 & 248 & 1238 & 2705 & 3793 \\
\hline B(E)PYRENE & 67 & 52 & 1326 & 3122 & 3930 \\
\hline Q(A)PYRENE & 127 & 338 & 9062 & 6244 & 10573 \\
\hline PERYLENE & 51 & 40 & 2244 & 3123 & 2888 \\
\hline $\begin{array}{l}\text { TOTAL SELECT AROMATICS } \\
\text { NAPHTHALENE } ~-\text { PERYLENE }\end{array}$ & 1132 & 2067 & 21647 & $28: 01$ & 49908 \\
\hline
\end{tabular}

N. 0.-CONCENTRATION IS S5MICROGRAMS/KILOGRAM DRY SEOIMENT 


\begin{tabular}{|c|c|c|c|c|c|c|c|c|c|c|}
\hline OEFTS IHTERYAL (CM) & $145-150$ & $135-140$ & $115-120$ & $100-95$ & $80-75$ & $40-45$ & $30-35$ & $20-25$ & $10-15$ & $0-5$ \\
\hline SA:PLE ORY WT./WET WT. & $0.7 \epsilon$ & 0.67 & 0.42 & 0.26 & 0.31 & 0.30 & 0.64 & 0.28 & 0.26 & 0.27 \\
\hline PODECEANE & 0 & 0 & 259231 & 232830 & 17214 & 3903 & 3177 & 3938 & 3103 & 5510 \\
\hline TARECALE & 0 & 0 & 145751 & 145463 & 22173 & 12455 & 1982 & 6537 & 5368 & $4: 28$ \\
\hline TETERTECAME & 0 & 0 & 69.430 & 65437 & 14612 & 2726 & $96 ?$ & 3659 & 2324 & 3467 \\
\hline P['TADUCA:EE & 0 & 26 & 157325 & $16<566$ & 22622 & 2094 & $102 b$ & 2924 & $247 ? 7$ & $5<05$ \\
\hline HEXAJECAUE & 0 & 0 & 19621 & 34804 & 13538 & $A B 1$ & 44 & $4: 13$ & 251 & 377 \\
\hline HEPILUECAYIE & 24 & 41 & 23532 & 9357 & 12735 & 1345 & 127 & 5439 & 783 & 1457 \\
\hline PHYTA"IE & 35 & 75 & 142968 & 19270. & 20.319 & 3055 & 225 & 2686 & $15 \% 9$ & 1439 \\
\hline DCTACECARL & 0 & 16 & 9015 & 3493 & 10458 & 1062 & 64 & 4045 & 1211 & 4552 \\
\hline PR!STAU:ER & 33 & 69 & 133023 & 17929 & 18906 & 2842 & 210 & 2499 & 1022 & 1333 \\
\hline IOS:ICECAIIE & 4 & 48 & 60898 & 16011 & 21474 & 827 & 323 & 2976 & 2173 & 4955 \\
\hline ErCoshi:E & $2 ?$ & 44 & 16830 & 3080 & 5903 & 2006 & 128 & 7047 & 4233 & 6365 \\
\hline HEOCICOSA JE & 54 & 83 & 9305 & 2392. & 2551 & 2351 & 161 & 9034 & 5281 & $9: 209$ \\
\hline C.cos: & 41 & 64 & 7645 & 1705 & 2197 & 1281 & 112 & 5274 & 5644 & 5693 \\
\hline IR. $1 \cos 2.1 E$ & 96 & 167 & $92 i 2$ & 1463 & 1506 & 2762 & 226 & 8344 & 5673 & 7844 \\
\hline IETHACOStHE & 11 & 68 & 8662 & 838 & 1672 & 2284 & 92 & 8354 & 4043 & 15072 \\
\hline PEITACOSAHIE & 305 & 470 & 138.34 & 1447 & 3676 & 5721 & 592 & 6584 & 8503 & 10141 \\
\hline HEXACOSAIE & 78 & 139 & 15429 & 957 & 5536 & 5479 & 231 & 13246 & $206 \theta$ & 17464 \\
\hline OETACOSATE & 43 & 84 & 20182 & 2592 & 5994 & 7853 & 224 & 9497 & 997 & 6507 \\
\hline TRICOSA:;E & 36 & 75 & 27610 & 2524 & 8590 & 5941 & 192 & 9612 & $! 614$ & 11026 \\
\hline HËUTRICOSAHE & 357 & 578 & 20140 & 1524 & 11171 & 11487 & 577 & 16538 & 2084 & 11226 \\
\hline $\begin{array}{l}\text { TOTAL SELECT SATURATES } \\
\text { C1) THR' C } 31 \text {. IRICLUDES } \\
\text { PHYTANE AND PEISTANE }\end{array}$ & 1163 & 2045 & 1169692 & 725688 & 222897 & 78553 & 10574 & 132397 & 60734 & 133228 \\
\hline
\end{tabular}


TABIE. 9.

CONCENTRATIONS OF AROMATIC HYOROCARBONS IN SECTIONS OF CORE BPS 30 CONCENTRATIONS ARE IN MICROGRAMS PER KILOGRAM DRY SEDIMENT (PPB).

\begin{tabular}{|c|c|c|c|c|c|}
\hline CORE DEPTH(CM) & $45-50$ & $30-35$ & $20-25$ & $10-15$ & $0-5$ \\
\hline DRY WEIGIIT : WET WEIGIIF & 0.30 & 0.64 & 0.28 & 0.26 & 0.27 \\
\hline NAPHTIMLENE & 831 & 7495 & 918 & 521 & .3143 \\
\hline BENZOTHJOPHF.NE & N.D. & 1172 & N.D. & N.D. & N.D. \\
\hline 2-METHYLNAPHTHALENE & 212 & 210 & 239 & 248 & 434 \\
\hline 1-METHYL NAPHTHALENE & 73 & 271 & 97 & 95 & 162 \\
\hline BIPHENYI. & 48 & 89 & 247 & 203 & 291 \\
\hline 2,6-DIMETHYL NAPHTHALENE & 146 & 48 & 127 & 133 & 169 \\
\hline $2,3,6$-TRIMETIINAPIITHALENE & 93 & 30 & 112 & 82 & 188 \\
\hline FLUORENE & 550 & 485 & 682 & 798 & 1018 \\
\hline DIBENZOTHIOPHENE & 146 & 80 & 211 & 284 & 124 \\
\hline PIJENANTHRENE & 1697 & 1158 & 2332 & 2214 & 2629 \\
\hline AN TIIRACENE: & 1090 & 335 & 1248 & 1332 & 1019 \\
\hline 1-METHYLPHENANTHRENE & 878 & 317 & 2712 & 1915 & 1817 \\
\hline FLUORANTHENE & 7050 & 3010 & 12465 & 14091 & 13715 \\
\hline PYRENE & 3106 & 1573 & 6077 & 6612 & 6788 \\
\hline CHRYSENE & 2555 & 578 & 4601 & 6060 & 1276 \\
\hline B(E) PYRENE & 882 & 185 & 709 & 560 & 845 \\
\hline 8(A) PYRENE & 4303 & 818 & 1277 & 2111 & 4778 \\
\hline PERYLENE & 949 & 1387 & 683 & 347 & 842 \\
\hline TOTAL SELECT AROMATICS & & & & & \\
\hline NAPHTHALENE - PERYLENE & 24607 & 19273 & 37761 & 37604 & 37536 \\
\hline
\end{tabular}

N. O. -CONCENTRATION IS < 5 MICROGRAMS/KILOGRAM DRY SEDIMENT. 
TABLE 10.

COMCENTRATIONS OF AROMATIC HYOROCARBONS IN SECTIONS OF CORE BPS 30.

CONCENTRATIONS ARE IN MICROGRAMS PER KILOGRAM ORY SEOIMENT (PPB).

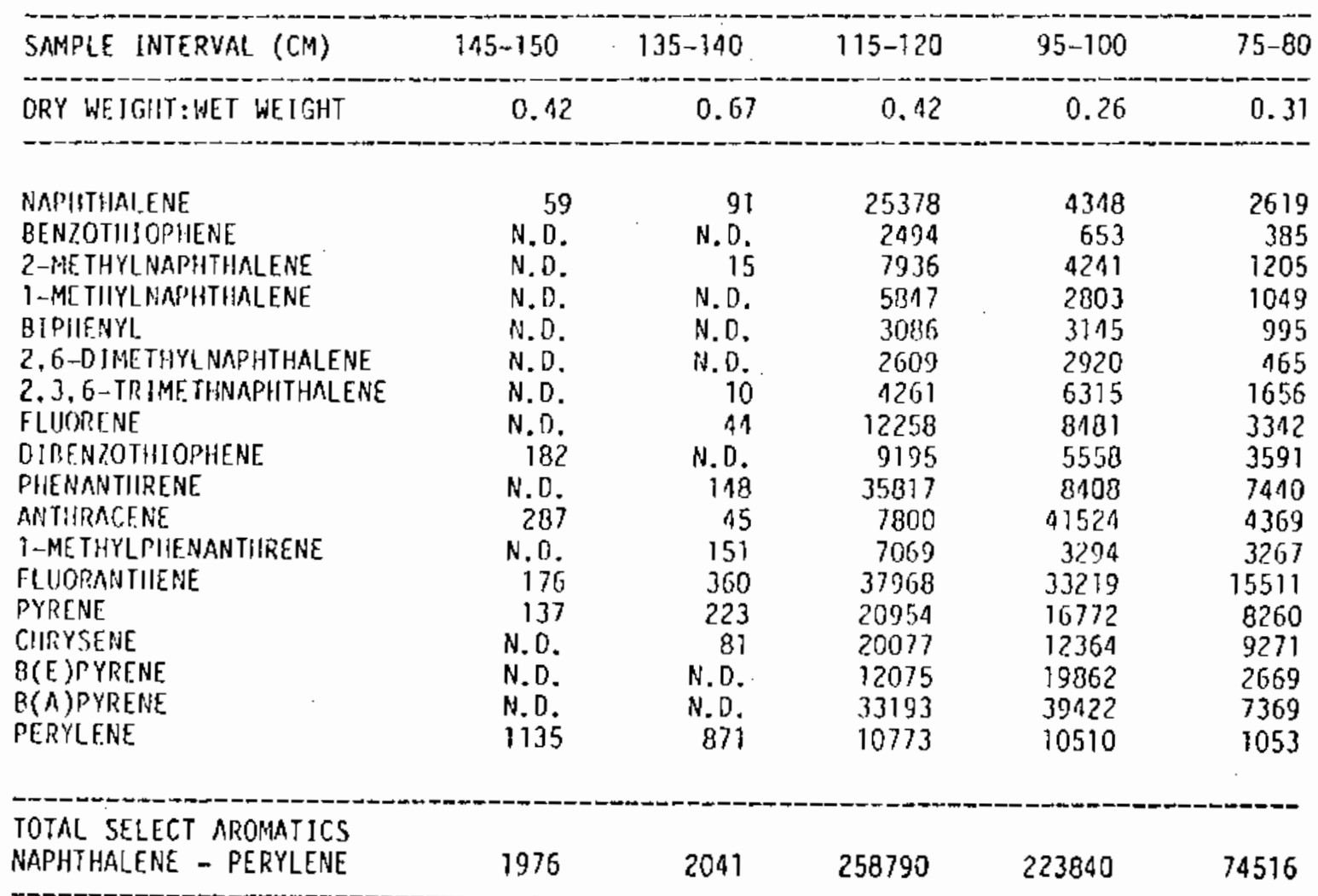

N.D. - CONCENTRATION IS <5 MICROGRAMS/KILOGRAM DRY SEDIMENT. 

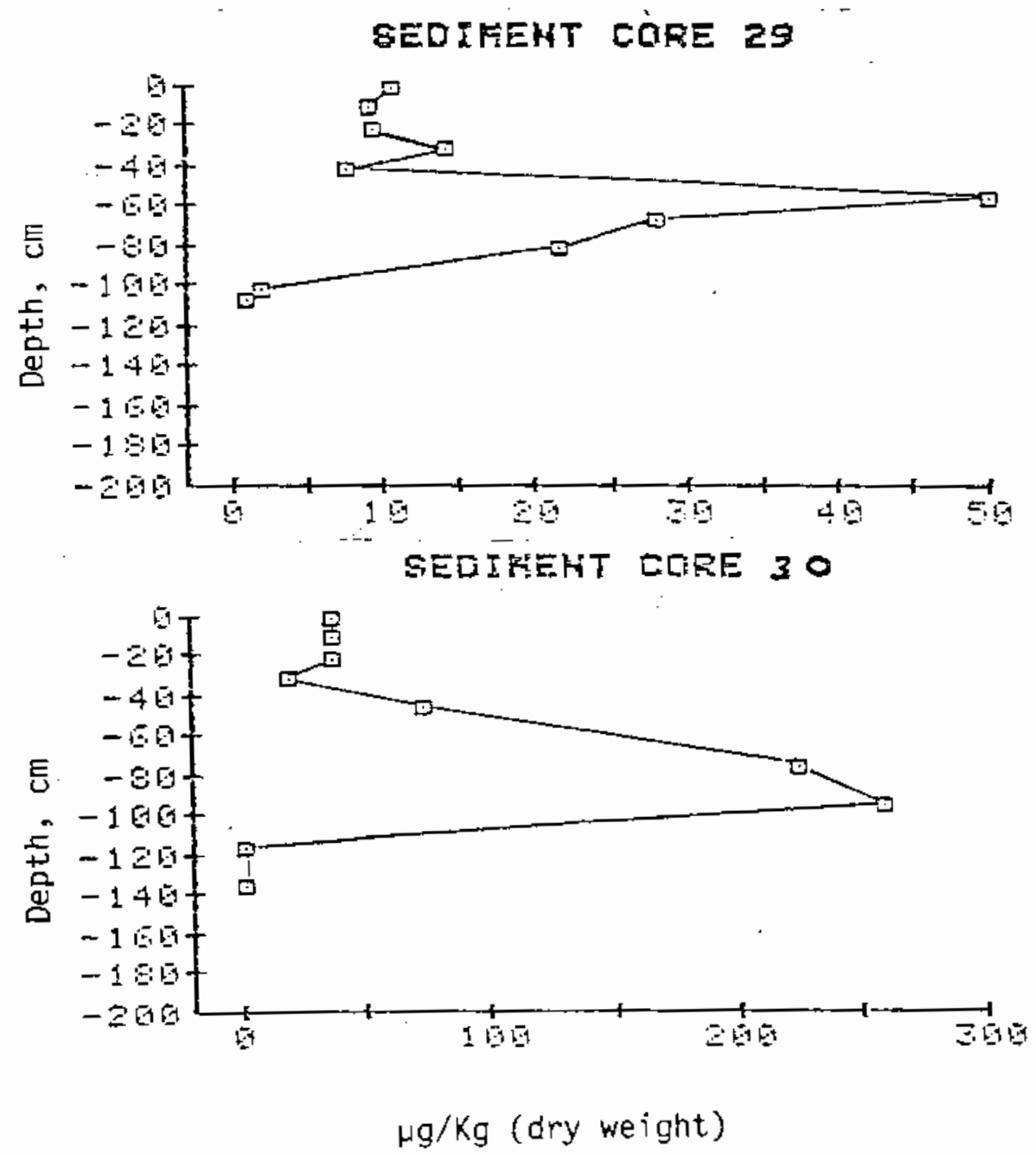

FIGURE 8. Concentration of total selected aromatic hydrocarbons in sediment cores. 
concentrations of selected aromatic hydrocarbons in some core sections appear to be similar to concentrations in some sediment cores analyzed from Waterways adjacent to Commencement Bay (Riley et al. 1981). A similar pattern was observed for $\mathrm{Hg}, \mathrm{Pb}$ and $\mathrm{Cu}$.

CHLORINATED ORGANICS

Six sediment samples were analyzed for PCBs and scanned for other chlorinated organic compounds in a semiquantitative manner. The identification of these other compounds was based on GC retention time relative to a known anaiytical standard only and to comparison to distribution patterns of the compound from our previously reported work.

The results of the PCBs analyses are listed in Table 11 and vertical profiles in sediment cores plotted in Figure 9. The maximum concentrations of PCBs was $1610 \mu \mathrm{g} / \mathrm{kg}$ (as Arochlor 1254) at depth interval 95-100 cm in Core 30 . Less than $10 \mathrm{\mu g} / \mathrm{Kg}$ PCBs were detected in the bottom sections of each core. Chlorinated butadienes (CBDs) were the other chlorinated organic compounds detected in the surface and mid-depth core sections. The only CBD compound that was quantified was hexachlorobutadiene which was approximately $100 \mu \mathrm{g} / \mathrm{Kg}$ in the mid-depth section of each core and $<13 \mu \mathrm{gg} / \mathrm{Kg}$ in the bottom section.

TABLE 11. Concentrations of PCBs as Arochlor 1254 in Sediments $(\mu \mathrm{g} / \mathrm{Kg}$ dry $\mathrm{wt})$

Core Stations

BPS -29

BPS -30
Depth (cm)

$0-5$

65-70

105- 110

0-5

95-100

145-150
PCBS

210

320

$<10$

1040

1610

$<10$ 

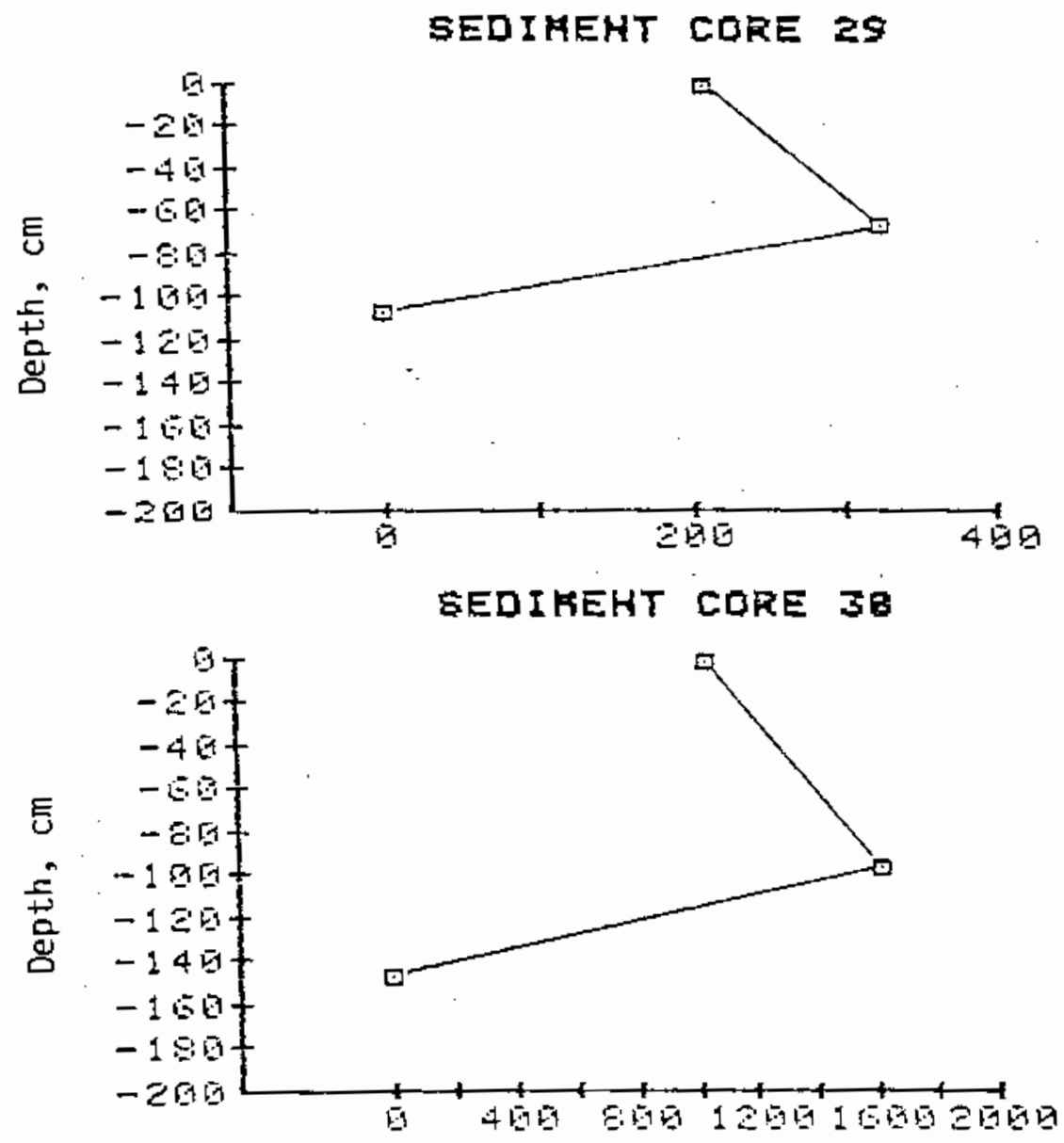

$\mu \mathrm{g} / \mathrm{Kg}$ (dry weight)

FIGURE 9. Concentration of PCBs as Arochior 1254 in Sediment Cores 



\section{CONCLUSIONS}

Based on the results of two cores, it appears that approximately 1 to 1.5 meters of sediment has been deposited in East Waterway since it was last dredged by the Corps in 1978.

The sediments of East Waterway are contaminated with $\mathrm{Hg}, \mathrm{Ag}, \mathrm{In}, \mathrm{Cd}$, $\mathrm{Pb}, \mathrm{Cu}$, saturated hydrocarbons, aromatic hydrocarbons and PCBs. Malins et al. (1982) reported similar concentrations for $\mathrm{Hg}, \mathrm{Cd}, \mathrm{Pb}, \mathrm{As}$ and aromatic hydrocarbons in a surface sediment collected near our Station BPS-29. Thejr results, compared to those reported in this study, are compared in Table 12.

The subsurface sediments contain as much as five times greater concentrations of contaminants than surface sediments. The thickness of contaminated sediments was between $0-110 \mathrm{~cm}$ at 5 tation BPS-29 and 0-130 cm at Station BPS-30. The sediments for deeper than $135 \mathrm{~cm}$ at Station BPS-30 contain lower concentrations of contaminants than surface sediments in Possession Sound or the main basin of Puget Sound (Pavlou et al. 1983).

TABLE 12. Comparison of the Concentration of Contaminants in East Waterway Surface Sediment ( $\mu \mathrm{g} / \mathrm{g}$ dry wt)

\begin{tabular}{ccc} 
Contaminant & $\begin{array}{c}\text { This Study } \\
\text { BPS-29, } \\
\mu \mathrm{g} / \mathrm{g}\end{array}$ & $\begin{array}{c}\text { Malins et a1 1982 } \\
\text { Station 2(05215), } \\
\mu \mathrm{g} / \mathrm{g}\end{array}$ \\
\hline $\mathrm{Hg}$ & 0.19 & 0.26 \\
$\mathrm{Cd}$ & 2.4 & 1.7 \\
$\mathrm{~Pb}$ & 37 & 36 \\
$\mathrm{As}$ & 13 & 19 \\
Aromatic & 10.8 & 5.1 \\
hydrocarbons & &
\end{tabular}





\section{REFERENCES}

Crecelius, E. A., R. G. Riley, N. S. Bloom and B. L. Thomas. (In press.) History of Contamination of Sediments in Commencement Bay, Tacoma, Washington. Prepared by Pacific Northwest Laboratory for NOAA/MESA, Richland, washington.

Malins, D. C., B. B. McCain, D. W. Brown, A. K. Sparks, H. O. Hodgins and S. Chan. 1982. "Title

NOAA Technical Memorandum OMPA-19, National Oceanic and Atmospheric Administration, Boulder, Colorado.

Paviou, S. P., R. F. Shokes, W. Hom, P. Hamilton, J. T. Gunn, R. 0. Muench, J. Vinelli and E. A. Crecelius. 1983. "Levels, Distribution, and Mass Balance of Toxicants in the Main Basin of Puget Sound and Lake Washington." Volume 1 of Dynamics and Biological Impacts of Toxicants in the Main Basin of Puget Sound and Lake Washington.

Metro Toxicant Pretreatment Plaming Study Draft Task C.I Report. Draft Final Report submitted to the Municipality of Metropolitan Seattle, Seattle, Washington.

Singleton, L. R., Dale E. Norton and C. Haynes. 1982. Water Quality of the Snohomish River/Estuary and Possible Impacts of a Proposed Hewlett Packard Manufacturing Plant. Washington State Department of Ecology, Olympia, washington.

Riley, R. G., E. A. Crecelius, M. L. O'Malley, K. H. Abel and D. C. Mann. 1981. "Organic Pollutants in Waterways Adjacent to Commencement Bay." NDAA Technical Memorandum OMPA-12, National Oceanic and Atmospheric Administration, Boulder, Colorado.

Riley, R. G., E. A. Crecelius, D. C. Mann, K. H. Abel, B. L. Thomas and R. M. Bean. 1980. "Quantitation of Pollutants in Suspended Matter and Water from Puget Sound." NOAA Technical Memorandum ERL MESA-49, Boulder, Colorado.

Environmental Protection Agency (EPA). 1983. Water Quality Management Program for Puget Sound: Part I. Management Activities, Data Requirements and Data Base. EPA Region 10, Water Division, Seattie, Washington. 

DISTRIBUTION

OFFSITE

No. of

Copies

15 J. Malek

Environmental Resources

U.S. Army Corps of Engineers

Seattle District

P.0. Box C-3755

Seattle, WA 98124

27 DOE Technica? Information Center

J. V. Dorigan

U.S. Department of Energy

ER-75 GTN

Washington, DC 20545

H. M. McCammon

Ecological Research Division

EV-34

Mail Stop E-201 GTN

Office of Energy Research

Washington, DC 20545
ONSITE

No. of

Copies

DOE Richland Operations Office

H. E. Ransom/P. K. Clark

6 Battelle, Marine Research Laboratory

E. A. Crecelius (4)

J. A. Trelstad

J. A. Strand

12 Pacific Northwest Laboratory

K. E. Byers (4)

R. G. Riley

Technical Information (5)

Publishing Coordination (2) 